\title{
Board Communities in Formation of Qanun Regional in Aceh Parliament
}

\author{
S. Amirulkamar ${ }^{1}$, Ismail ${ }^{2}$ \\ ${ }^{1}$ UIN Ar-Ranirry Banda Aceh, Indonesia \\ ${ }^{2}$ Lecturer in University of Iskandarmuda, Indonesia \\ sayedamir61@gmail.com
}

\begin{abstract}
The Government system of the Unitary State of the Republic of Indonesia according to the 1945 Constitution of the Republic of Indonesia recognizes and respects special or special regional government units (Special in the Religious Field, Special in the Field of Education and Special in the Customary Field) regulated by Constitution. In this case the Regional People's Representative Council (DPRD), which is abbreviated as DPRD, but names Aceh as a Provincial Region in the Unitary State of the Republic of Indonesia system based on the 1945 Constitution of the Republic of Indonesia and the title of elected government official will be determined by the DPRA after the 2009 general election. This is only a change in the legal nomenclature with the status remains in the position of Aceh Privileges. This long journey is the existence of the Council community in the formation of the Regional Qanun in the Aceh Parliament in the form of a legislative body as one of the tools of the DPRA that manages the formation of the Regional Qanun which is carried out jointly with the Regional Head. This is done with the delegation of government authority to the Regional Regions as a political tool in the struggle for human rights and the rights of social aspirations, as well as the Aceh People's Representative Council or the Aceh DPR as a nomenclature of legislative institutions in regions that have legitimated importance in governance. The regulation of laws and regulations in Indonesia as a constitutional basis for the 1945 Constitution of the Unitary State of the Republic of Indonesia article $18 \mathrm{~B}$ paragraph (1) states that "the State recognizes and respects special or special regional government units that are regulated by laws invite.
\end{abstract}

Keywords

community council; formation of Qanunregional

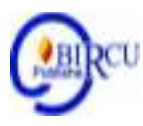

\section{Introduction}

Referring to the DPRA institution which is a Regional Representative of the People's Representative and is in the Province of the Province which is domiciled as an element of regional governance as referred to in article 10 article 1 of Law Number 11 Year 2006 concerning the governance of Aceh, states that "Aceh DPRD, hereinafter referred to as the Aceh People's Representative Council (DPRA) is an organizer of the Aceh Regional Government whose members are elected through general elections". 
Konfrontasi Journal: Culture, Economy and Social Changes, 7 (1) March 2020, 29-39

ISSN: 1410-881X (Print), 2716-2095 (Online)

\section{S. Amirulkamar, Ismail: Board Communities in Formation of Qanun Regional in Aceh Parliament DOI: https://doi.org/10.33258/konfrontasi2.v7i1.94 \\ http://www.konfrontasi.net/index.php/konfrontasi2}

By having such legal status, the DPRA establishes the DPRA's capability tools in the form of the Legislative Body as the center for planning the formation of regional qanun with a permanent status, so the DPRA has the same responsibilities as the regional government but has different versions in carrying out the wheels of regional government. But this development aims to build mutual understanding in a government that does not supervise each other through "Immediate step in proportion to the shoulders, becoming one in building regional missions". This means that the DPRA as an element of regional administration as a working partner and has a position in line with the head of the region.

When looking back politically in article 94 of law number 9 of 2015 concerning the Second Amendment to Law Number 23 of 2014 concerning Regional Government, it states that "Provincial DPRD is composed of members of political parties participating in elections elected by general election". Although the regional government was built together (executive with the legislature, as outlined in the Domination of Local Political Parties in the Aceh Parliament in responding to the Aspirations of the Community by S. Amirulkamar, this togetherness was greatly supported if there was a balance in the implementation of the task, instead it created inequality such as Discussion The House Board is a tough tool and does not include the National Party Serti Karya Group (Golkar), the Democratic Party (PD) and the United Development Party / Nasdem Party (PPP / Nasdem-Combined) even though article 6 paragraph (2) Government Regulation Number 12 of 2018 About Guidelines for the Arrangement of Provincial, Regency and City DPRD Regulations This function aims to strike a balance between social stability and community change, in accordance with the legal system applying rules regarding correct and appropriate behavior, social control, including all forces that create and maintain ties social ties in I'm a political party.

In the Elucidation of article 12 paragraph (1) of Qanun Number 3 of 2007 concerning the Procedures for Forming Qanun, it states as follows:

Qanun draft academic paper is a manuscript that contains the background, the purpose of the preparation, the objectives to be realized and the scope, scope, objects or direction of the regulation of Qanun design which is scientifically accountable. Academic study of Qanun design is a study of the contents of Qanun design that has been prepared by the proponent which is studied academically from an Islamic, philosophical, juridical and sociological perspective.

In the council community in the formation of Qanun regional in Aceh's parliament, the Aceh People's Representative Council (DPRA) has socialized Aceh Qanun Number 5 of 2011 challenging the procedures for making Qanun to the district / city government. This is as the function of the formation of regional regulations (Perda) and / or Qanun Regional by the DPRD (DPRA) can be implemented in accordance with law number 9 of 2015 concerning the Second Amendment to Law Number 23 of 2014 concerning Regional Government.

\section{Review of Literature}

\subsection{Political Theory}

Politics is an attempt to achieve a society that is better than it faces. According to Peter Merkl (1967: 13) Politics at its best is a noble quest for a good order and justice, which means; Politics in its best form is an effort to achieve a good and just social order. Thus we can understand that politics is an attempt to determine regulations that are acceptable to most people to bring society towards a better and harmonious life.

Efforts to achieve a harmonious life in relation to politics can certainly be done with a variety of activities, which among others, relate to the process of determining the goals of the system, as well as ways of carrying out these goals. Society makes decisions about what is 
the goal of the political system, and the choice of several alternatives and the priority order of the goals that have been determined.

David Easton (Suharno, 2010: 69) added that the Political System is outlining the political system model in the formulation of policies and objectives. This model is based on the concepts of information theory (inputs, withinputs, and feedback) and views public policy as a response of a political system to the forces of the social, political, economic, cultural, geographical and so on that are around it. Thus, in this model public policy can be seen as the output of the political system.

The concept of a political system means that a number of political institutions and activities in society function to change inputs in the form of demands, supports and resources into decisions or policies - authoritative policies for all members of society (outputs). So in short that the political system functions to change inputs into outputs. And the essence of a decision making itself is the process of determining choices (Sharf, 1992: 303).

\subsection{Government Theory}

Government is an organization composed and composed of a group of people who have the power or who are given the power to manage and control. C.F. Legal Specialist Strong in Dahlan Thalib argues that government comes from the word government which gets the suffix "an". So the government is an organization that is given the right to exercise sovereign power. In a broader sense, the government is something bigger than the body of ministers, an understanding that is often used today when referring to the cabinet in Britain as an example of the current government (Dahlan Thalib, 2004: 7-14).

A similar view was also expressed by Moh. Kusnardi and Harmaily Ibrahim (1988: 171) that government can be seen from two sides, the government in the broad sense and the government in the narrow sense. "Government in the broadest sense is all affairs carried out by the state which are carried out to carry out the welfare of its people and the interests of the state itself; While a narrow government is a government that only carries out executive duties. Therefore, discussing the government system is discussing how the division of power and the relationship between state institutions that carry out the powers of the state, in the context of organizing the interests of the people.

As a government, in this case a country, of course, must have: first, military power; second, legislative or legislative or legislative authority; third, financial power or ability to raise sufficient funds from the public to finance national defense and law enforcement made on behalf of the state. In short, the state must have legislative, executive and judicial powers, which are called the three powers in government.

Juridically, the government especially in Indonesia is divided into two, namely the central government and regional governments. The Central Government is a government that has overall power, and has the power to take all policies deemed necessary for the welfare of the people, starting from the central level to the regions. While the regional government is the ruler in the region, and in making certain policies must get approval from the central government, except policies that are only local and limited.

To regulate between the central and regional authorities to run properly and proportionally, the government has regulated them through the law. In Article 1 paragraph 2 of Law No. 32 of 2004 concerning Regional Government, that Regional Government is the administration of government affairs by the regional government and the DPRD according to the principle of autonomy and assistance tasks with the broadest possible principle of autonomy in the system and principles of the Unitary State of the Republic of Indonesia as referred to in The 1945 Constitution of the Republic of Indonesia. 


\subsection{Theory of Regional Autonomy}

Autonomy comes from the Greek word "autos" which means itself and "namos" which means Law or regulation. Suparmoko (2002: 61) means that regional autonomy is the authority of autonomous regions to regulate and manage the interests of local communities according to their own initiatives based on community aspirations. While what is meant by regional autonomy according to Law No. 32 of 2004 article 1 paragraph 5, the definition of regional autonomy is the right, authority and obligation of the autonomous region to regulate and manage their own government affairs and the interests of the local community in accordance with statutory regulations.

Thus regional autonomy is a policy and authority given by the central government to regional governments to regulate and manage their own regional needs in accordance with the existing and developing needs in the area.

In line with the meaning of regional autonomy as mentioned above. In the explanation of Law No. 32 of 2004, it was stated that the granting of the authority of regional and district / city autonomy was also based on decentralization in a. A form of broad autonomy, b. Real autonomy and c. Autonomy is responsible.

What is meant by the authority of broad autonomy is the freedom of the region to hold a government that covers all fields of government except in the fields of foreign politics, security, justice, monetary and fiscal, while religion and authority in other fields are determined by statutory regulations. In addition, the autonomy freedom also includes full and unanimous authority in the implementation of planning, implementation, supervision, control and evaluation.

While real autonomy is the freedom of the region to exercise governmental authority in certain fields that actually exist and are needed and grow and develop in the region. While Responsible Autonomy is in the form of the realization of accountability as a consequence of granting rights and authority to the regions in achieving the objectives of giving autonomy in the form of improving and improving people's welfare, developing democratic life, justice and equity and maintaining a healthy relationship between the center and the regions and between regions in order to maintain the integrity of the Unitary Republic of Indonesia.

\section{Research Methods}

The approach used in this research is to use a qualitative descriptive approach, meaning that the problem solving process uses data that are expressed verbally and the classification is theoretical, not processed through mathematical calculations with various statistical formulas. Data collection techniques are done through interviews and documentary studies. Data analysis is the process of organizing and sorting data into patterns, categories and basic units of description so that themes can be found and work hypotheses can be formulated as suggested by the data. The job of data analysis in this case is to organize, sort, classify, provide code and categorize it. The organization and management of the data aims to find work themes and hypotheses which are eventually adopted as substantive theories. Data analysis in qualitative research is more focused during the process in the field together with data collection.

\section{Discussion}

\subsection{How to Make a Responsive Qanun in the Administration of Regional Government}

Legislation is any decision written by the competent official in legislative authority based on attribution or delegation authority or executive authority solely based on authority 
based on delegation authority whose material content contains rules which are of a general, binding nature. Basically, the dependence of the Council in making this Regional Qanun on the Executive, because of the large owned by the Regional Head with the dominance of government as article 40 of Law 11 of 2006 concerning the Government of Aceh, states as follows:

1. The Governor because his position is also a representative of the government;

2. In his position as government representative, the Governor is responsible to the President. On the other hand, article 207yat (1) of Law number 9 of 2015 concerning the Second Amendment to Law Number 23 of 2014 concerning Regional Government states that "Work Relations between the DPRD and Regional Heads are based on equal partnership".

Understanding the alignment and equality that was built by the togetherness of the regional government but in the nomenclature of the applicable law remains significantly different operation in which the Regional Head is significantly elected by the people and supported by the people including the supporting political parties to become the Regional Head in full control of regional leadership and as a tool of the central government existing in the area through the delegation of authority. The authority referred to as decentralization, Deconcentration and Co-administered Tasks as numbers (8), (9) and (11) law number 9 of 2015 concerning Second Amendment to Law Number 23 of 2014 concerning Regional Government, states as follows:

Number (8) Decentralization is the transfer of Government Affairs by the Central Government to the Autonomous Region based on the Autonomy Principle;

Number (9) De-concentration is the delegation of part of Government Affairs which is the authority of the Central Government to the Governor as the representative of the Central Government, to vertical agencies in certain areas and / or to the Governor and Regent / Mayor as the governor of government affairs. Number (11) Assistance Task, is the assignment of the Central Government to an autonomous region to carry out part of the Government Affairs which are the authority of the Central Government or from the Provincial Government to the Regency / City Region to carry out a portion of Government Affairs which are the authority of the Provincial Region.

In making regional Qanun, along with the development of the nature of the thought of maturity and society is increasingly increasing with Science and Technology (Science and Technology) and Faith and Taqwa. This development creates transparency that requires boundaries of thinking areas built by local governments, especially the DPRA legislative body, by addressing the making of Qanun which requires up-date information about Qanun and its substance so that responsive community needs can be met in the administration of local government both in terms of legal or non-legal aspects of law.

Judging from the legal aspect, the existence of a hetorogenic society in which applies a variety of knowledge, religions and customs with a variety of social status, but the existence of the law in the form of Qanun remains in its territory which is generally dominated by community culture. Therefore Marcus Tullius Cidero mentions that "Ubi Societas, Ibi Ius" means where there is a community, there is also a law.

In the reality of life there is a legal pressure that is adjusted to the existence of local civilization so that the application of Qanun can run effectively, is recognized, followed, lived and finally cultivated as a need and not for the sake of. When reviewed non-legal aspects, towards the application of a regulation in the form of regional Qanun in existing social life and effectively applied based on the initiative and the work of the community itself in an effort to crystallize Qanun through the purpose of living in the state, building togetherness through increasing legal ideals as a legal container and community construction in force through the establishment of regional Qanun. 


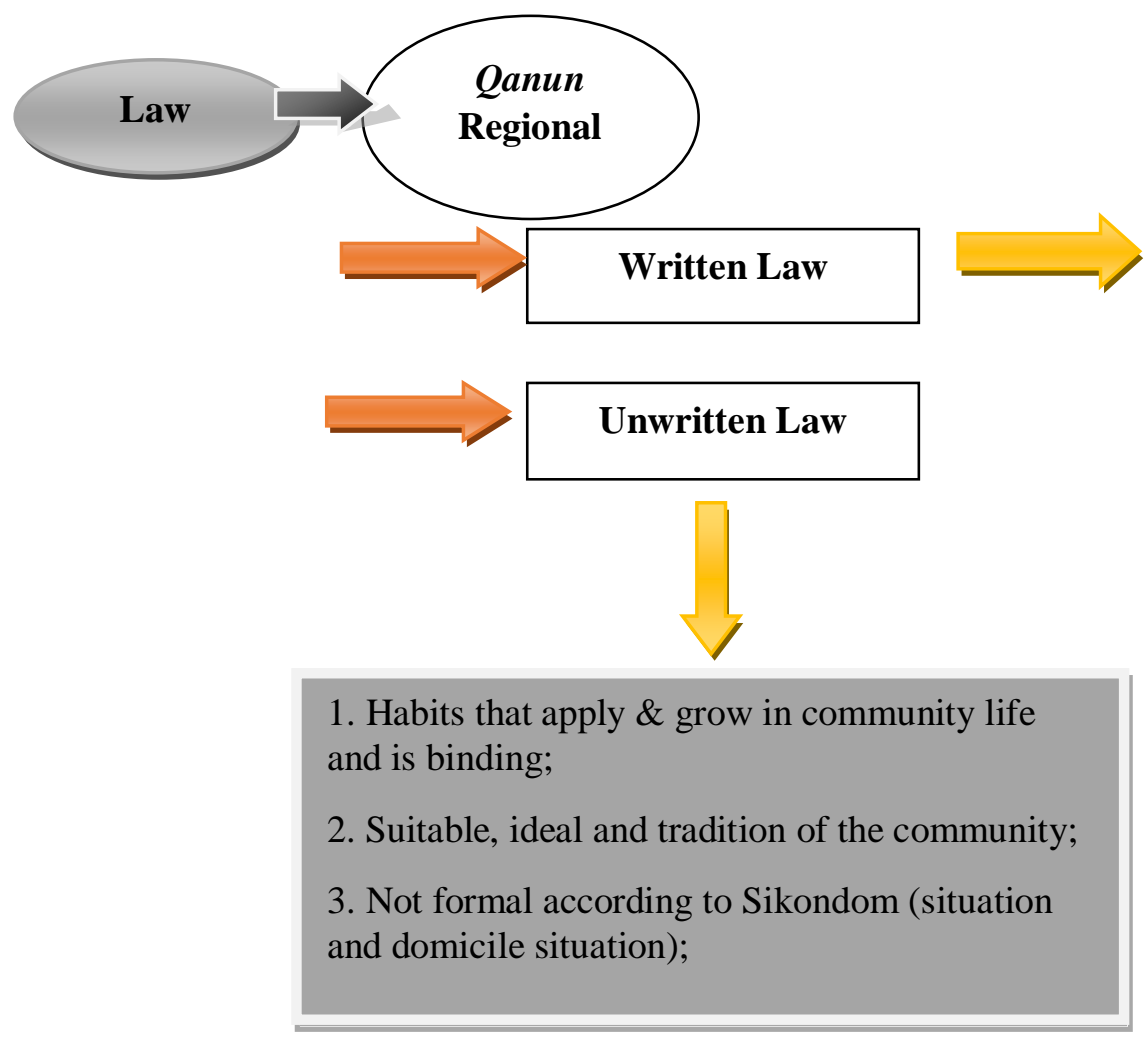

1. Arrangement of the life substance of Qanun and easily understood by the public;

2. The level of ability (knowledge) is adjusted to the community to avoid understanding legal uncertainty;

3. Providing ease and discrimination according to SOP;

4. Development of reasoning with innovation \& creativity

Source: Data Processed in 2020

Figure 1. Systematic implementation of Qanun Regional

In general responsive as $\mathrm{KBBI}$ is: fast (likes) to respond, are responsive, moved, and responding (not stupid). Other meanings of the word responsive are responsive, responsive, moved, responding (not indifferent). Every application that is used produces information that comes from a collection of data and documents before being processed into a form of information that is proven true is called a data set. According to Lubis (2016: 1) states that "Data are facts that describe an actual event at a certain time".

Thus seen from the sector of public life how to make a responsive Qanun in accordance with the requirements of the community in the administration of the Regional Government, contains the factors forming Qoanun Regional in the form of:

1. Does not cause multiple interpretations and ambiguities so that it cannot be used as a legal certainty from the implementation of a regional legal product;

2. Does not damage the constitutional law order so that it is necessary to dynamically be consistent in the formulation of a regional qanun;

3. To regulate and determine new material that is in line with the development of legal needs that are current and do not conflict with the existence of the above law;

4. Has the substance of systematic qanun material and structured according to the qanun method and language and ethics;

5. Maintaining harmonization of making qanun in stages with the applicable rules above means that it does not conflict.

According to Anhar (2010: 1) states that "Data is a reality that describes an event and is a real unity that will later be used as a basis for information". So it can be concluded that the data is data stored in the form of a file where the data is not yet processed but is stored to give certain meaning to people who need the data. 


\subsection{Community Council in Developing their Capacity to be More Effective, Participatory and Transparent in Making Qanun Regional}

When referring to the law, thus implicitly, article 94 and 95 paragraph (1) and (2) Law number 9 of 2015 is about the second amendment to law number 23 of 2014 concerning regional government states as follows:

a. Article 94, the Aceh DPR consists of members of political parties participating in general elections who are elected through general elections;

b. Article 95 paragraph (1) Provincial DPRD is a representative institution of the people of the provincial region which is domiciled as an organizer of the provincial regional government;

c. Article 95 paragraph (2) Members of the provincial DPRD are provincial regional officials.

This illustration shows that the composition and position of the DPRA in the Province as regional officials must be made as equal as possible with the Regional Head. In this case articles 121 and 122 letter (l) of Law Number 5 in 2014 concerning State Civil Apparatus has been arranged in such a way that there is a separation between structural, functional officials and political officials (DPRA), as follows:

a. Article 121, employees of the State Civil Apparatus can become state officials;

b. Article 122, state officials as referred to in article 121 letter (1), namely the Governor and Deputy Governor, letter (m) Regent / Mayor and Deputy Bupoati / deputy mayor, letter (n) Other state officials determined by law.

Clearly, the status of membership (DPRA Leaders and Members) and / or provincial level as a state official is illustrated, more politically oriented. This is generally stated that the DPRD is a regional House of Representatives which is located as an element of regional government and not as a state official. The Council community in developing their capacity to be more effective, participatory and transparent is elaborated in making the Regional Qanun, elaborated as follows:

\section{a. More Effective Capacity}

In the council community in the form of a Legislas Body in the making of qanun is basically very limited and only the scope of the region concerned and does not apply to other regions, therefore it is necessary to address the scope of the enactment of the above regulations to dominate the regions because they are national in charge of the regions.

In juridical manner (jurisdiction of welding and being the authority (van rechtswege nicting), on the principles of enforcement of regulations through:

a. Lex superior derogat lege inferiori (lower regulations do not conflict with higher regulations);

b. Lex specialis derogat lege generalis (special rules override general rules);

c. Lex posterior derogat lege priori (the new rule overrides the old one);

d. Non retroactive (rules may not apply retroactively).

The objectives to be achieved in qanun are not in conflict (overlapping) the regulation or abuse of authority by making jointly by the executive and legislative. Law Number 12 of 2011 concerning Formation of Regulations and Regulations is the implementation of the Article's order 22A of the 1945 Constitution of the Republic of Indonesia which states that "Further provisions regarding the procedure for establishing a law are further regulated by law.

It is clear that the legal force in the legislation is in accordance with the hierarchy as in Article 7 paragraph (1) and (4) of Law 12 of 2011 concerning the Formation of Legislation, states as follows: 
Hierarchy is the classification of laws and regulations, which should not contradict the lower laws and regulations; Considering the scope of the enactment of regional regulations only limited to the area concerned while the scope of the enactment of the Minister covers the entire territory of the Republic of Indonesia, then in the hierarchy of the Ministerial regulation is above the regional regulation.

The functions that need to be elevated in the formation of regional qanun are carried out in a manner as Suwanda (2016: 18) mentions as follows:

a. Discuss with the regional head and give approval or not on the proposed Ranperda (Ranqanun);

b. Submitting proposals for Regional Regulation (Ranqanun);

c. Arranging a program for the formation of Regional Regulations (Qanun) with regional heads.

Here is illustrated the function of the formation of a qanun is inseparable from the authority of the regional head rather than the authority of the DPRA, but Qanun owns and is held by the DPRA in order to produce output in the form of a Qanun which is discussed jointly with the regional head.

\section{b. Participatory}

Participatory development as a symbol of regional progress in relation to the performance of regional governments in the implementation of regional autonomy, is largely determined by the effectiveness of the role of DPRA Qanun formation. This is a manifestation of the DPRA in supporting the role of de-peers with the assumption that various regional development programs can be implemented when the program has been approved by the DPRA in the form of Qanun. This connotation of the DPRA must be wise with local wisdom in determining the ideal qanun by carrying out accuracy, accuracy and foresight oriented to the parameters produced by the DPRA legislative body.

\section{c. Transparency}

De jure (based on law) and de facto (based on facts) the making of Qanun by the DPRA can come from the Executive (Regional Head) and may also be from the Legislature (DPRA as an initiative qanun. Article 36 of the 12-year Law 2011 concerning the Formation of Legislation, states as follows:

1. The preparation of the Provincial Regional Legislation Program between the Provincial DPRD and the Provincial Government is coordinated by the Provincial DPRD through the equipment of the Provincial DPRD which specifically deals with the field of legislation.

2. Compilation of Provincial Regional Legislation Program within the Provincial DPRD is coordinated by the Provincial DPRD equipment that specifically handles the field of legislation.

3. The preparation of the Provincial Regional Legislation Program within the Provincial Government is coordinated by the law firm and can involve the relevant vertical agencies.

4. Further provisions regarding the procedure for the preparation of the Provincial Regional Legislation Program within the Provincial DPRD as referred to in paragraph (2) shall be regulated by a Provincial DPRD Regulation.

5. Further provisions regarding the procedure for the preparation of the Provincial Regional Legislation Program within the Provincial Regional Government environment as referred to in paragraph (3) shall be regulated by a Governor Regulation.

Qanun is made by the legislative body of the DPRA to hold a Public Hearing Meeting (RDPU) so that the public can understand the truth of the field facts from the concoction of the qanun that will be applied later. Emphasis as political transparency that is accountable openness. This can be done by describing the making program Qanun Regional as follows: 


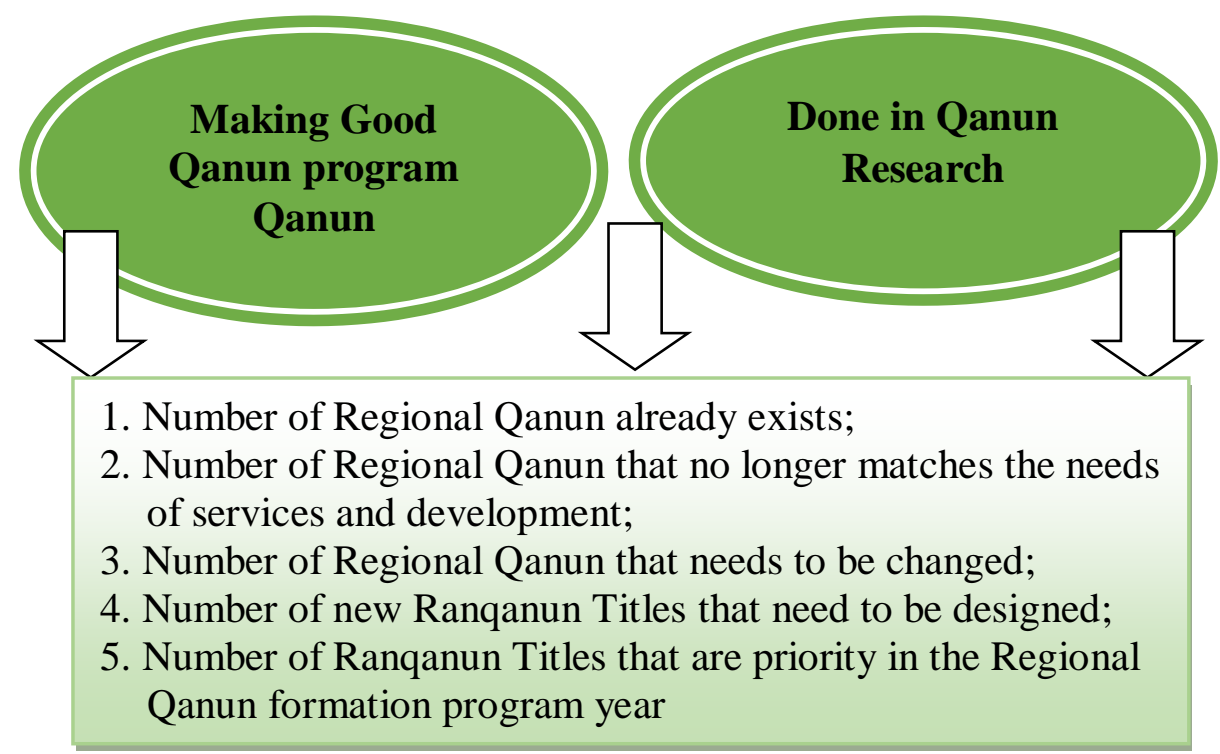

Source: Processed from various data in 2020

Figure 2. Planning qanun at the Aceh DPR

In transparency the regional qanun has various functions after being established as a qanun as Suwanda (2016: 30) mentions as follows:

1. As a policy instrument to carry out regional autonomy and assistance tasks as mandated in the 1945 Constitution and Law Number 23 of 2014 About Regional Government;

2. the implementing regulations of the higher laws and regulations;

3. In this function, Regional Regulations (qanun) are subject to the provisions of the hierarchy of statutory regulations, therefore local regulations must not conflict with higher regulations;

4. As a reservoir of regional specificity and diversity and channeling the aspirations of local communities, but in its arrangement it remains in the corridor of the Unitary State of the Republic of Indonesia based on Pancasila and the 1945 Constitution;

5. As a development tool in improving regional welfare.

Referring to Law number 12 of 2011 concerning the formation of Legislation Regulations, it states that "The process of establishing Regional Regulations is a series of activities in the preparation of regional legal products consisting of 4 (four) stages from planning, drafting, discussing up to stipulation and endorsement ".

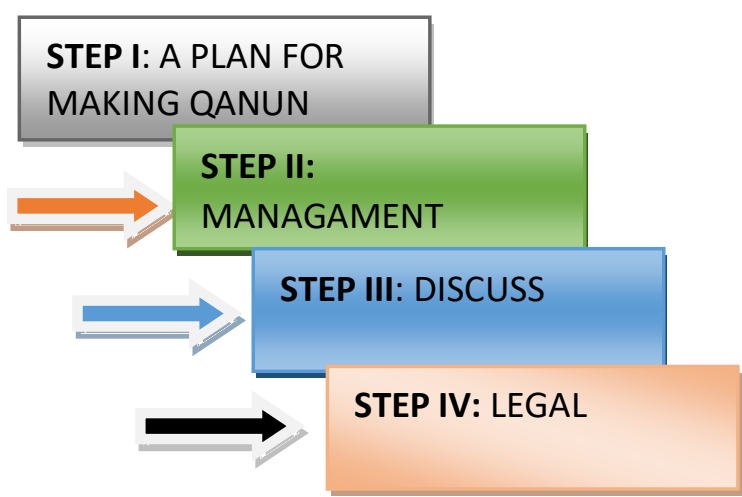

Source: Suwanda (2016: 50)

Figure 3. The process of forming a Regional Regulation / Qanun 
Which cannot be separated from the making of this Qanun Regional is a philosophical foundation, with the description that the regional regulation (Qanun) was formed with the orientation of life outlook, awareness and legal ideals that involve kebathinan in the philosophy of the Indonesian nation which originated from Pancasila, Opening of the 1945 Constitution and Pancasila. The sociological foundation as the foundation laid down on the facts and demands of the community's needs in encouraging the importance of the Regional Qanun as something that is needed by the community with arrangements. Whereas the Juridical Basis arranges the substance related to the material formed with Qanun Regional by prioritizing the systematic discussion and determination of the present.

\section{Conclusion}

1. In many cases members of the Aceh DPR even though they are considered as regional officials, in other legal nomenclatures it is not stated as a state official;

2. State officials recognized in Indonesia in accordance with article 121 of law number 5 of 2014 concerning State Civil Apparatuses (ASN) generally do not include leaders and Members of the DPRA but it is stated that "ASN employees can become State Officials", whereas in article 22 from letter (a) to letter (n) also do not include leaders and members of the Aceh and City Regency DPR;

3. The Aceh DPR as a representative body of the provincial region as a representative of the electoral district is domiciled as an element of regional government consisting of members of political parties participating in general elections elected through elections;

4. In the implementation of the functional tasks of the Aceh DPRD as an embodiment of the formation of Qanun (discussing jointly with executives), budgeting (discussing jointly with executives / SKPA) and supervision (Administrative and not technical and offensive actions).

\section{References}

Agustino, Leo. (2014) Edisi Revisi, Dasar-dasar Kebijakan Publik, Bandung: IKAPI Penerbit Alfabeta.

Amirulkamar, Sayed. (2017). Kebijakan Protokoler Pimpinan dan Anggota DPRA (Studi Implementasi Kebijakan Kedudukan Protokoler dan keuangan Pimpinan dan Anggota DPRA berdasarkan Qanun nomor 2 tahun 2007).

Budiardjo, Mariam. (2014). Dasar-dasar Ilmu Politik. Jakarta: Gramedia Pustaka Utama. Bungin, Burhan. (2013). Metodologi Penelitian Kuantitatif. Jakarta: Kencana.

Djojohadikusumo. (2013). Dinamika dan kapasitas dewan perwakilan rakyat daerah dalam tata pemerintahan demokratis, Erlangga, Jakarta.

Dwiyanto, Agus, et al. (2014). Reformasi Birokrasi Publik di Indonesia. Yogyakarta: Pusat Stusi Kependudukan dan Kebijakan UGM.

Dunn, William N. (2013). Pengantar Analisis Kebijakan Publik. Yogyakarta: Gajahmada University Press.

Gaffar, Affan. (2012). Otonomi Daerah Dalam Negara Kesatuan. Yogyakarta: Pustaka Pelajar.

Islamy, M. Irfan. (2013). Prinsip-Prinsip Perumusan Kebijaksanaan Negara. Jakarta: Bina Aksara.

Juliansyah. (2013). Sistem Politik Indonesia Pasca Reformasi. Bandung: Mandar Maju. Kaho, Josep Riwu. (2012). Prospek Otonomi Daerah di Negara Kesatuan Republik Indonesia, Jakarta: Raja Grafindo Persada.

Kacung, Marijan. (1212). Sistem Politik Indonesia. Jakarta: Kharisma Putra Utama. 
Lubis, Fahmi, et al. (2016). Hukum Persaingan Usaha antar Teks dan Konteks, Jakarta: GTZ Press.

Maleong, Lexy J. (2014). Metodologi Penelitian Kualitatif. Edisi Recvisi, Bandung: PT. Remaja Rosdakarya.

Miriam, Budiarjo. (2013). Partisipasi dan Partai politik. Jakarta: CSIS.

Nisjar, Karhi dan Winardi. (2012). Teori Sistem dan Pendekatan Sistem dalam Bidang Manajemen. Bandung: Mandar Maju.

Pranarka, dan Vidhyandika. (2013). Pemberdayaan Konsep, Kebijakan dan Implementasi dalam, Pemberdayaan (Empowerment). Jakarta: CSIS.

Prijono, Onny S dan Pranarka. (2012). Pemberdayaan Konsep, Kebijakan dan Implementasi. Jakarta: CSIS.

Prasetya, Irawan. (2014). Metodologi Penelitian Administrasi. Jakarta: UT.

Riyant, Nugroho. (2014). Public Policy: Teori, Manajemen, Dinamika, analisis, Konvergensi dan Kimia Kebijakan. Jakarta: PT Elex Media Komputindo

Sedarmayanti. (2014). Manajemen Sumber Daya Manusia, (Reformasi Birokrasi dan manajemen Pegawai Negeri Sipil), 2014. Bandung: PT. Refika Aditama.

Sekaran, Uma. (2014). Research Methods For Business: Metodologi Penelitian Untuk Bisnis. Jakarta: Salemba Empat

Sugiyono. (2016). Metode Penelitian Kualitatif. Bandung: Alfabeta.

Sutrisno, Edy. (2013). Budaya Organisasi, Jakarta: Kencana Prenadamedia Group. Soetanyo. (2012) Metode Penelitian Kualitatif, Bandung: CV Alfabeta.

Suwanda, Dadang. (2016). Peningkatan Fungsi DPRD (dalam penyusunan Perda yang responsive). Bandung: PT. Remaja Rosdakarya.

Undang-undang Nomor 11 Tahun 2006 Tentang Pemerintahan Aceh.

Undang-undang Nomor 2 Tahun 2008 Tentang Partai Politik dan Qanun Aceh Nomor 3Tahun 2008 Tentang Partai Lokal Peserta Pemilu Anggota DPR Aceh dan DPR Kabupaten/Kota.

Undang-undang Nomor 12 Tahun 2011 tentang Pembentukan Peraturan perundangundangan dan Qanun Aceh Nomor 3 Tahun 2007 tentang Tatacara Pembentukan Qanun.

Undang-undang nomor 9 Tahun 2015 tentang Perubahan Kedua atas undang-undang nomor 23 Tahun 2014 tentang Pemerintahan Daerah, Jakarta: Sinar Grafika.

Winarno, Budi. (2014). Teori dan Proses Kebijakan Publik. Yokyakarta: Media Presindo. 